\title{
CHANGES IN THE MANAGEMENT OF THE IRISH UPLANDS: A CASE-STUDY FROM THE IVERAGH PENINSULA
}

\author{
Eileen O'Rourke', Nadine Kramm²
}

Received 27 August 2008; Accepted 16 December 2008

\begin{abstract}
European upland landscapes are of high natural and cultural value. In this paper we present a case study, set in the Irish uplands. We highlight the complex links between ecology, farming systems, the policy environment and the local socioeconomic and cultural context. Given the current low economic returns from hill sheep farming, pluriactivity and multifunctionalism are increasingly necessary farm household coping strategies. We argue that the part-time farming model has land use management and ecological implications for the uplands. Overall we find that within the social-ecological system studied, farming households are adjusting to changing circumstances rather than exiting the sector en mass. We conclude that effective policies for the conservation and management of the uplands, requires a cross-sectoral approach that can take account not only of environmental criteria, but also land managers socio-economic objectives.
\end{abstract}

Key words: Iveragh Peninsula, upland ecology, sheep farming, agricultural policy, socialecology system.

\section{Introduction}

The uplands, which can be broadly defined as areas above the upper reaches of enclosed farmland, have traditionally been depicted as marginal, peripheral places, where time stood still. Or as Berger (1992: 220) put it - 'the periphery was where the past ended up'. Today, this prognosis is only partly true; while mountain agriculture remains less profitable than lowland agriculture (Strijker, 2005; Flury et al., 2005; Baldock et al., 1996), increasingly the uplands are seen as important high nature value landscapes, with high ecological, landscape and recreational value. The Irish uplands, which extend over half a million acres, are important repositories for biological diversity and contain priority habitats, such as blanket bog and heaths, as listed under Annex 1 of the European Habitats Directive (92/43/EEC). Upland heather moorlands, as found in Ireland, Scotland, and western parts of Britain and Norway, are one of the most distinctive sub-montane habitats found in Europe (Thompson et al., 1995; Usher \& Thompson, 1998; Pearsall, 1968). These internationally important semi-natural habitats were fashioned by a combination of physical factors, climate and human agro-pastoral systems. In England and Scotland upland moorland estates are managed for the shooting of red grouse and red deer, as well as for sheep grazing and forestry. In Ireland the uplands are essentially

\footnotetext{
${ }^{1}$ Dr. Eileen O'Rourke, Department of Geography, University College Cork, National University of Ireland, College Cork, Cork, Ireland, e-mail: e.orourke@ucc.ie

${ }^{2}$ Nadine Kramm. Department of Geography, University College Cork, National University of Ireland, College Cork, Cork, Ireland
} 
managed by farming practices, notably extensive sheep grazing and rotational burning. Today, it is changes in the farming system that poses the greatest immediate threat to the Irish uplands. It is expected that climate change may also be a factor in the near future. The case study presented in this paper relates to the Iveragh peninsula, which forms part of the Kerry uplands in SW Ireland (see Figure 1). The aim of the paper is to explore this complex socialecological system, especially the links between the ecology of the uplands, policy driven farming systems and socio-economic factors on the ground. This research is based on: (a) detailed biodiversity field data, (the collection and analysis of which is ongoing and the preliminary results will not be presented here); (b) a detailed farm management survey which was administered to 80 upland sheep farmers on the Iveragh; (c) over forty five semi-structured interviews with hill sheep farmers, and (d) three stakeholder meetings, with the principal actors in the area, including farmers, farm advisors, conservationists, and representatives of the tourist and leisure industry.

\section{The Iveragh Peninsula}

The Iveragh peninsula forms the westernmost part of Ireland and of Europe. It is surrounded by the Atlantic Ocean on three sides, and measures $60 \mathrm{~km}$ in length by $30 \mathrm{~km}$ in width. It comprises an area of 139,137 hectares $(343,802$ acres), $65 \%$ of which is classified as uplands, with the highest peak being Carrantoohil at $1,041 \mathrm{~m}$ (3,414 feet), within the sharply glaciated Macgillycuddy's Reeks mountain range. The dominant underlying rock is Old Red Sandstone, with outcroppings of Carboniferous Limestone and Valencia Slate Formation. It enjoys a temperate Atlantic climate with a mean temperature range of $7^{0}$ to $16^{\circ} \mathrm{C}$. The mean annual average rainfall is $1,350 \mathrm{~mm}$, increasing to 3,000 in elevated sites. Given the peninsula's mountainous topography, high rainfall and poor waterlogged peaty acidic podzolic soils, it is not surprising that the entire area is designated as severely handicapped under the European Less Favoured Areas Directive (Regulation 950/97). The principal form of agriculture practiced here today is extensive sheep farming. Approximately $8 \%$ of the peninsula is planted with fast growing conifers. However, given that most of the Iveragh uplands are designated as both Special Areas of Conservation (SAC) and 'Acid Sensitive', it is unlikely that the area under forestry will expand much in the future. The towns of Killarney, Kenmare, Killorglin and Cahersiveen are important retail and service centres, for this otherwise isolated and sparsely populated rural hinterland. The peninsula encompasses the scenic 'Ring of Kerry', a designated area of outstanding natural beauty, and is one of the most important tourist destinations in the country. In particular, the towns of Killarney and Kenmare on the eastern part of the peninsula, where it joins the mainland, are major tourist hubs.

\section{Ecology}

Shallow blanket bog is the predominant vegetation type in the Iveragh uplands, dominated by communities of ling/heather (Calluna vulgaris), deer sedge (Trichophorum caespitosum) and grasses such as bog cotton (Eriophorum spp.), mat grass (Nardus stricta), and especially purple moor grass (Molinia caerulea), as well as several important bryophytes (Sphagnum spp.), lichens (Cladonia) and flowering herbs. While blanket bog vegetation is generally found on flat or gently undulating terrain, wet heaths are more commonly associated with moderately steep slopes with poor drainage. On acid soils, purple moor grass is favoured with increasing slope, while rushes (Juncus spp.) are found in wetter areas. Dry heaths are found in steeper areas of well drained shallow peats or mineral soils, with dwarf shrubs, such as ling and bell heather, gorse (Ulex gallic) and bilberry (Vaccinium myrtillus), and small grasses (Agrostis spp.) (cf. Anderson, 2008; MhicDaeid, 1976; Dunne, 2000). The Iveragh uplands are also home to some internationally important bird species, including the grouse (Lagopus scoticus), hen harrier (Circus cyaneus), golden plover (Pluvialis apricaria), and the recently reintroduced white tailed sea eagle (Haliaeetus albicilla), all listed under Annex 1 of the EC Birds Directive (74/409/EEC). 


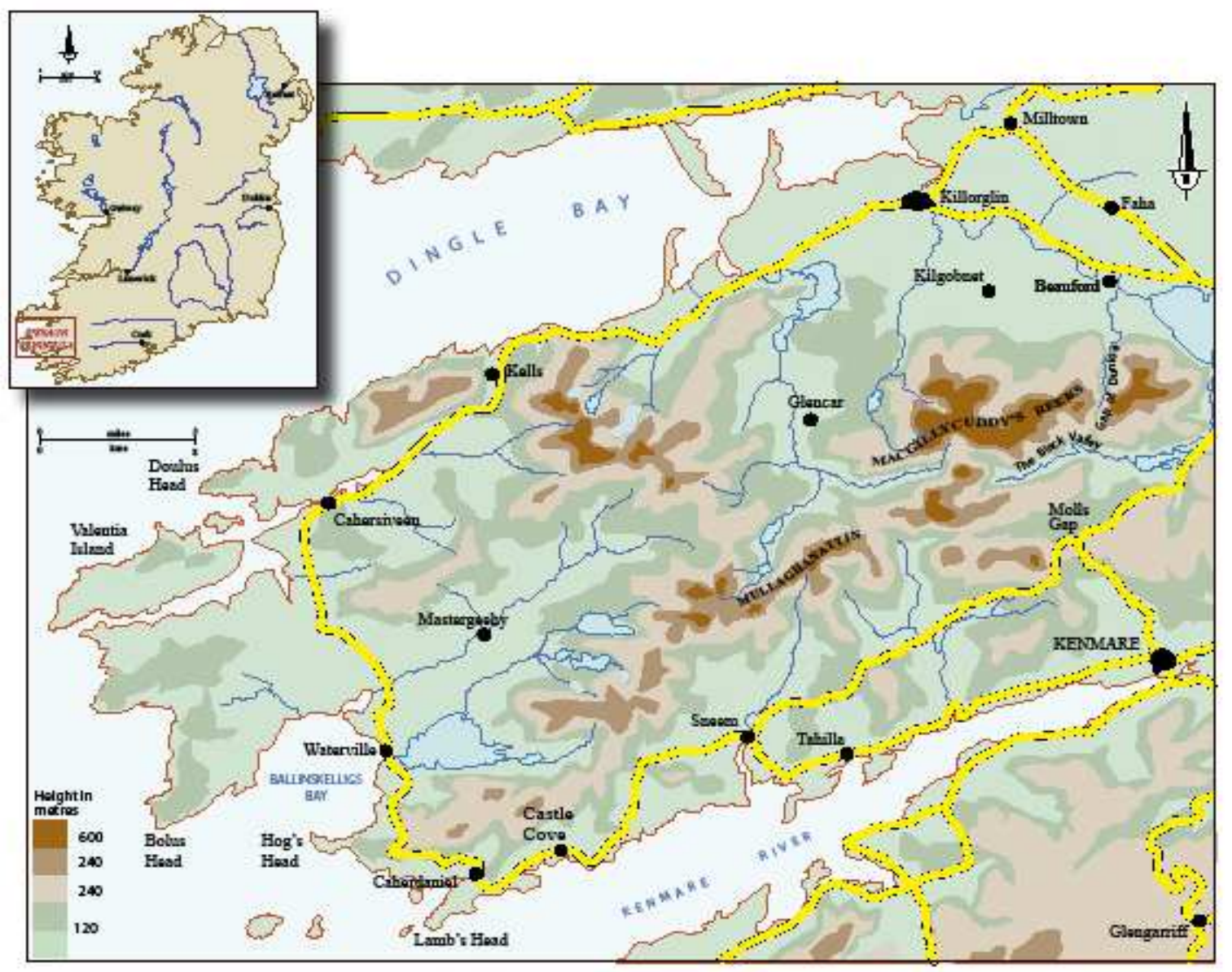

Fig. 1. Location map showing the Iveragh Peninsula

The ecology of the uplands is intimately linked with past and present farming systems, in particular grazing practices and also the use of fire. Darling and Boyd (1969:135), remind us that 'grazing as an ecological factor is the meeting ground of natural history and pastoral husbandry'. We cannot dissociate the two. Under high grazing pressure heather moorlands shift to grasslands, dominated by such species as purple moor grass and mat grass (Thompson et al., 1995; Ratcliffe, 1959). In recent times the overgrazing of the Irish uplands, driven by European agricultural policy incentives, led to the degradation of many of these habitats, resulting in the exposure of bare peat in the more extreme cases, or the incursion of invasive species such as mat grass (Nardus stricta) and bracken (Pteridium aquilinum). Today, under a different policy environment, under-grazing and possibly land abandonment are emerging as the major threats to the upland habitats of the Iveragh peninsula. Before describing changes in traditional upland farming practices, it is important to first understand the integral role played by upland commonages.

\section{The Commons}

Commonage is an old form of holding land in common, which in Ireland is thought to date back to the Early Medieval period. The holding of land in common has long disappeared from the lowlands (with the exception of some coastal areas, known as Machair), but due to the physiology of the uplands it has persisted there. There is approximately half a million ha of land registered as commonage in Ireland, found mostly along the peripheral western seaboard. South Kerry contains 71,000 ha of commonage, distributed between the Iveragh and Dingle peninsulas (see Figure 2). Commonage is restricted to members of the shareholders of the commonage and is not 'open access' (Di Falco \& van Rensbury, 2004). The Iveragh commonages are generally large tracts of mountain on which a number of shareholders have either grazing rights or ownership rights. Traditionally ones portion of the commons was calculated in terms of a 'collop' - or the grazing equivalent of one cow (1cow $=6.66$ ewes). Upland commonages are widely recognised as being of exceptional conservation and 
recreation value (Bleasdale, 1995; Bleasdale \& Sheehy-Skeffington, 1995). Legally the commons occupy a grey area, and today there is a lot of ambiguity surrounding access and grazing rights. One could also argue that this legal ambiguity along with their marginal position has protected the commons from agricultural improvement and afforestation in the past, and thus their high biodiversity status today (Kramm et al., 2008).

The upland commons are also the areas that suffered most from overgrazing from the 1980s on, when EU sheep headage subsidies encouraged the stakeholders to overstock the commons. The traditional social control mechanisms succumbed to the greed of maximising individual profit - reinforcing Harding's (1969) celebrated thesis of the 'Tragedy of the Commons'. In 1998, under pressure from Europe, the Irish Government (Department of Agriculture and Dúchas, the Heritage Service), introduced the Commonage Framework Plan (CFP), which brought about a compulsory $30 \%$ destocking of all commonages ${ }^{3}$. On inspection by a team of experts, the destocking level could be raised up to $100 \%$. The farmers were compensated for all animals destocked.

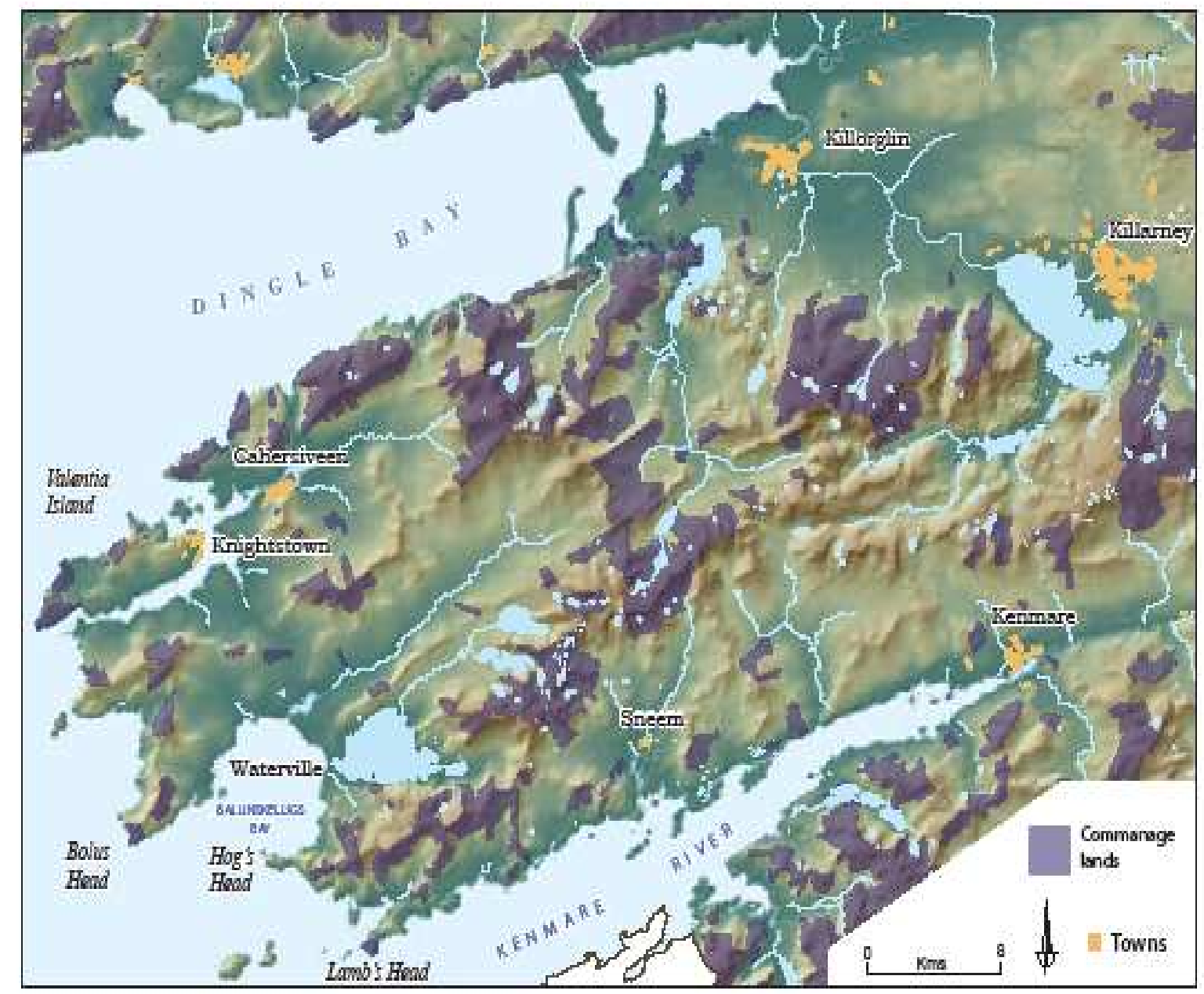

Fig 2. Map of the Iveragh Peninsula showing upland commonage land (Source: National Parks and Wildlife Service NPWS).

\section{Traditional Farming Systems}

A traditional hill farm on the Iveragh typically consists of some improved reclaimed grassland, known as 'green land' (or 'in bye land'), along with large tracks of upland rough grazing, either privately owned or held in commonage (see Photos 1 \& 2). The green land, frequently placed around the dwelling house, plays a critical role in determining the farm's stocking capacity. Traditionally sheep remained outdoors all year round, being brought down to the green land around the lambing period, at the end of March or in early April. They remain there until the

${ }^{3}$ Commonages already covered by the voluntary agri-environmental, Rural Environmental Protection Scheme (REPS), were exempt from the CFP, as they were deemed to be already sustainably grazed. 
lambs are strong enough to follow their mothers up the hills for summer grazing, around early June. The resultant store mountain lambs were traditionally sold in the autumn (August/September) to lowland producers for fattening. The majority of the female lambs were kept as replacements for older ewes. The green land is also used to produce winter fodder, such as hay or silage. Farmers without sufficient green land have to rent lowland farms in other parts of the peninsula. Under the traditional hill sheep farming system, the out-wintered sheep received supplementary feeding only during times of extreme weather, for example when there was snow on the ground, and around lambing time. The traditional sheep breed on the hills is the Scottish Blackface of Kerry type (along with some Cheviots), which are well suited to the rigours of the uplands.

In recent times there have been some important changes to the traditional hill farming system, again with ecological consequences. The first point to note is that in the past sheep were not the sole grazers of the Kerry uplands. Prior to 1900s, it was cattle (especially the rustic Kerry cow) not sheep that dominated the uplands (O'Rourke 2008). Until recently a mixed sheep and cattle system was the norm, whereby two to three year old cattle were put on the uplands over the summer to graze the strong grasses, which sheep would not eat, and trample the bracken ${ }^{4}$. The decline in cattle grazing in the uplands is associated with the current spread of less desirable vegetation such as bracken (Pteridium aquilinum), gorse (Ulex europaeus) and hard rush (Juncus inflexus). Bracken is a known carcinogen which is poisonous to both cattle and horses, but is less toxic to sheep and deer (cf. Darling and Boyd 1969; Winter et al. 1998). Cattle and horses are more effective than sheep at controlling the strong grasses and trampling the bracken. Pearsall (1968) reminds us that previous history is at least as important as existing habitat conditions in determining the vegetation type. Or, put another way, we now know that plants have a 'memory'. Consequently, temporal as well as spatial scales are critical in the assessment of biodiversity.

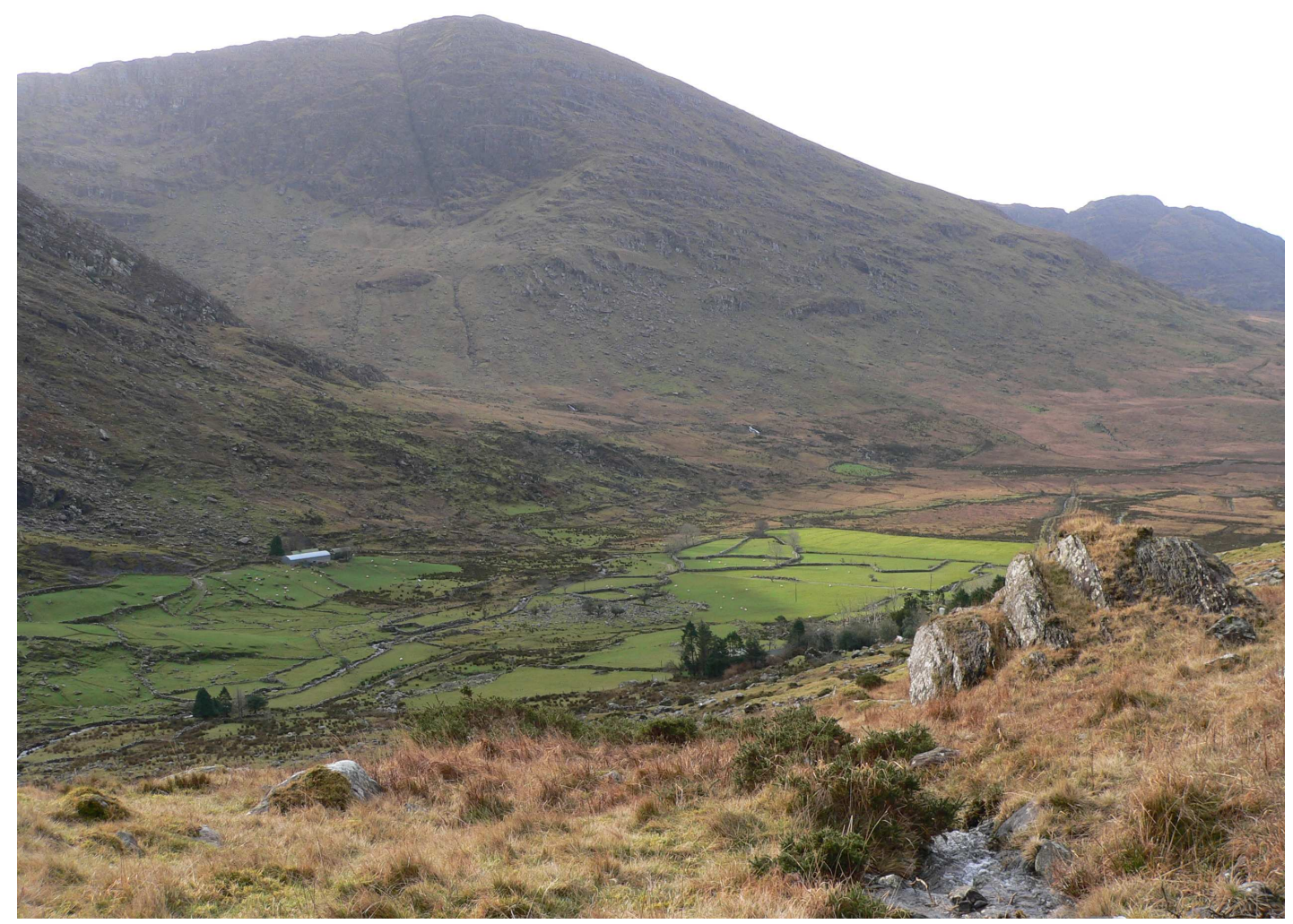

Photo 1. The Iveragh Uplands, showing improved 'Green Land' in the mid-ground (Source: N. Kramm)

\footnotetext{
${ }^{4}$ Under EU regulations the rustic Kerry suckler cow is classified as a dairy breed and consequently does not qualify for the important beef premium. Grazing the uplands by cattle has encountered another obstacle under the agrienvironmental REPS scheme, which stipulates that farmers have to fence off upland rivers and streams from cattle, but not sheep. Fencing the uplands is a very difficult and costly task, with fencing posts frequently having to be dropped by helicopters.
} 
It is due to changes in the agricultural policy environment, that the Iveragh uplands are today almost exclusively associated with sheep farming. Ireland joined the European Union in 1973, and subsequently its agriculture has been profoundly influenced by the Common Agricultural Policy (CAP). The dominance of sheep on the Iveragh uplands was given a major boost with the introduction of the European Mountain Lamb and Hogget Ewe scheme in the 1970s, (Directive 75/268); and the introduction of the European Ewe Premium in 1980 (Regulation 1837/80), whereby an annual subsidy was paid per head of ewes. Subsequently sheep farming became a numbers game, with up to an overall doubling (even tripling) in stocking densities on the Iveragh and throughout the country - (see Table 1). According to local farmers, prior to the ewe premium the average stocking density was one sheep to the acre in the mountains, after the premium it rose to 2 sheep or more to the acre ${ }^{5}$. The overgrazing and frequent burning of the uplands, led to the disappearance of the dwarf shrubs, such as heather \& bilberry, and the dominance of a grass and sedge species poor vegetation, along with the incursion of invasive species such as bracken, matt grass and heath rush.

\begin{tabular}{|l|r|r|r|r|r|r|}
\hline Agricultural Statistics for Sheep & & & & & & \\
\hline Date & $\mathbf{1 9 3 3}$ & $\mathbf{1 9 5 4}$ & $\mathbf{1 9 6 5}$ & $\mathbf{1 9 7 5}$ & $\mathbf{1 9 8 0}$ & $\mathbf{2 0 0 0}$ \\
\hline Cahersiveen Rural District & 37489 & 51077 & 47392 & 61719 & 65116 & 109282 \\
\hline Kenmare Rural District & & 49410 & 55358 & 71494 & 77120 & 108820 \\
\hline Killarney Rural District & & 32473 & 34317 & 37923 & 36915 & 82187 \\
\hline
\end{tabular}

Tab 1. Evolution of Sheep Numbers on the Iveragh Peninsula - consisting of the Cahersiveen Rural District, and parts of the Kenmare and Killarney Rural Districts.

(Source: Agricultural Census, Central Statistics Office (CSO), Dublin).

The carrying capacity of the hills was expanded by supplementary feeding of sheep with concentrates and hay or silage, along with the construction of slatted units, to house some of the sheep over the winter and around lambing time. Under the headage subsidy regime, it also became more profitable for lowland producers to rear their own lambs. This in turn forced the more production oriented hill farmers to finish their lambs on expensive concentrates, and sell them straight to the factory. One of the ecological consequences of supplementary feeding is that the sheep congregated around the feeding points and are less likely to forage for themselves up the mountain. Given the intricacies of farming practices, including different altitudinal grazing, seasonality, animal breeds, dietary preferences, foraging behaviour and supplementary feeding, stocking levels on their own are too crude a measure of the relationship between herbivores and vegetation (Kramm 2008; Wathern, 1992).

The traditional mountain store lamb weighs about $20 \mathrm{~kg}$, and requires a lot of feeding on concentrates to bring it up to the 30-40 kg lamb export markets now demand. Under the current globalised world markets, the light weight Iveragh store lamb has to compete with imports from places like New Zealand and Argentina. Two thirds of Irish lamb is destined for the export market. Prices for Irish lamb in 2007 were the same as in the early 1980's, about $€ 75$ for a 20 $\mathrm{kg}$ lamb, which in turn retails in the supermarket at €270 (IFA Communication, 2008). Under the general intensification of the sheep farming system, and in order to satisfy new market demands for heavier lambs, the Blackface mountain sheep breed is frequently crossed with more lowland breeds, such as the Texel, Suffock and Charollis. This has resulted in a 'softening' in sheep breeds; they are no longer suited to the rigours of the high uplands, they do not forage as well as the rustic breeds and require supplementary feeding over the winter (O'Rourke, 2008). However, the pure bred mountain lamb is a slow grower, and it takes about twelve months to finish it for the market; whereas the lowland lamb and cross-breeds can be ready for the market in six months. We come to see how farming systems, type, age and breed of grazers, along with shifting policy regimes have major impacts on the ecology and management of the uplands, as well as on the social systems embedded in these landscapes. Today, there is a need to improve hill sheep breeds, along with more appropriate management of the uplands.

\footnotetext{
${ }^{5}$ The farm management survey indicates that the average stocking density on the 80 farms surveyed today is 0.29 LU/ha (LU=Livestock Unit). Most heather occurs in moorlands with stocking levels $<0.28$ LU/ha (or 2 ewes/ha) (MacDonald \& Armstrong (1989).
} 


\section{Impact of the Single Farm Payment}

Due to a combination of the Irish Commonage Framework Plan (CFP), and especially the introduction of the EU Single Farm Payment (SFP) in 2005, which essentially decoupled EU agricultural support subsidies from production, the overstocking of the uplands has effectively been resolved, at least on paper. The SFP would appear to provide a tremendous incentive to destock, as farm incomes are now based on an average of all the subsidies received in the reference years $2000,2001,2002^{6}$, regardless of current stocking levels. Both under-grazing (at an extreme case land abandonment), and over-grazing, adversely affect the biodiversity of upland peat and heather moorlands (MacDonald et al., 2000; Thompson et al. 1995; Bignall \& McCracken, 1996; Ball et al., 1982). In the early stages of abandonment MacDonald et al. (2000:57) stated that biodiversity is likely to decrease as aggressive pioneer or dominant species invade. In the medium term as scrub cover develops, the spatial degree of biodiversity may increase, but then tends to decline as the woodland canopy closes. Should scrub and tree cover develop on the Iveragh uplands, it would mark the end of its rare biodiversity associated with its heather moorlands and blanket bogs. It would also transform the current open landscape, with aesthetic and recreational implications. It is expected that the fire risk would also increase. There are already increased incidences of summer gorse and heather wildfires on the Iveragh.

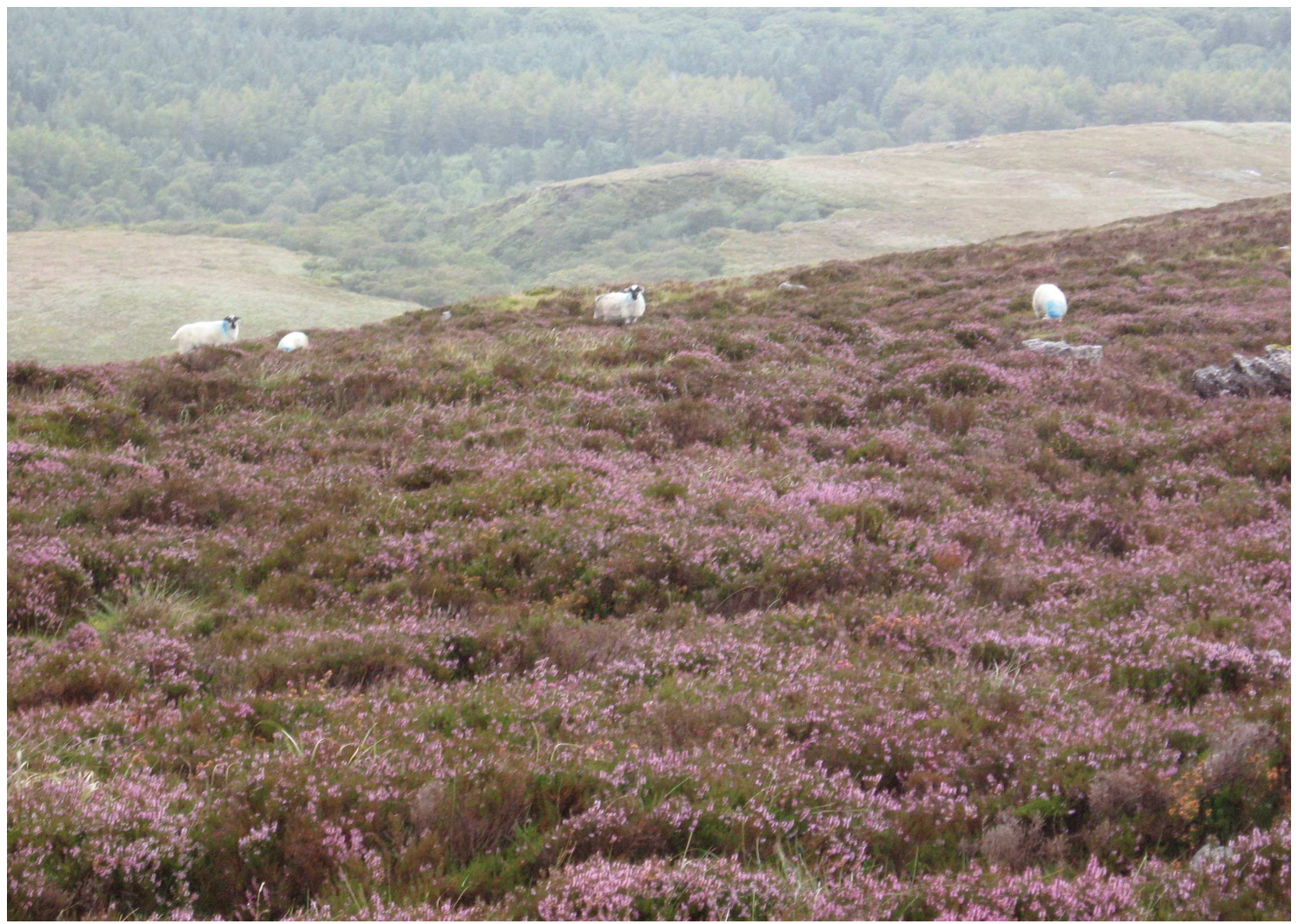

Photo 2. Upland Heather Moorlands on the Iveragh Peninsula being grazed by Blackface sheep Source: R. Anderson

It is still too early to evaluate the effects of the SFP policy on the ground, and it is difficult to quantify the current level of destocking ${ }^{7}$. Seventy six percent of the Iveragh hill farmers surveyed stated that they had reduced their stocking levels since the implementation of the SFP. The general impression is that they are cutting back to the pre 1980 'sustainable' stocking level. However, farmers tend to be conservative, and they have seen many farm subsidies come and go, and they remain slightly suspicious of all of them. Their typical response being, 'we will wait and see'. The SFP is guaranteed only until 2013. Farmers reason that if they cut back too drastically now they may have no quotas for restocking in the future should the policy environment change. They also point out that if they seriously cut back on sheep numbers, it

\footnotetext{
${ }^{6}$ The reference years for sheep in Ireland are 1997 and 1998, prior to the imposition of the Commonage Framework Plan.

${ }^{7}$ Nationally sheep numbers have fallen from 7.5 million in 2000, to 5.5 million in 2007 (www.cso.ie).
} 
would be difficult to reconstitute a good breeding flock in the future; that would know and settle in a particular heft.

Besides, many of the older farmers point out that they are used to maintaining a particular herd size (something they have always done), regardless of whether it makes economic sense or not, their identity and social status in the community is tied up with farming and herd size. However, the younger farmers, who are invariably involved in off-farm work, are far more inclined to cut back in stocking levels, and simplify their farming system. These are the people who openly state that they do not want their off farm work (or that of their spouse) to be used to subsidise their farming (O'Rourke 2008). They now know exactly where their farm income comes from, and they are adamant about cutting back input costs, such as supplementary feeding, fertiliser use and veterinary costs. Even if the current trend among the Iveragh's upland sheep farmers is towards extensification, the part-time farming model has led to a simplification of the management system, resulting in localised over and under grazing. The part-time farmer tends to favour the more intensive use of the reclaimed 'green land', and reduced grazing on the high uplands, thus cutting down on time consuming and labour intensive herding in the mountains. This in turn results in more extensively managed and species poorer uplands. The previously communal management tasks of periodic burning and the maintenance of mountain fences are also neglected. A case study by MacDonald et al. (2000) of agricultural restructuring in several European mountains, found that a typical adjustment scenario was a mixture of abandonment and intensification on different parts of a holding, or on land under different tenure arrangements. The Iveragh had adopted a similar polarised management strategy. MacDonald et al. (2000), also reminds us that abandonment is associated with an inability to adapt farming and land management to social and economic pressure.

\section{Economics of Hill Sheep Farm Survival}

The current income from sheep farming in Ireland (as elsewhere in the EU) is derived 125\% from subsidies (Teagasc, National Farm Survey 2005 - www.agriculture.gov.ie). Teagasc, which is the National Farm Advisory and Research Body, found that nationally the average Family Farm Income (FFI) form mainly sheep systems in 2003 was $€ 12,900$, and in 2005 it was $€ 15,935^{8}$. The 2005 national farm survey also found that on $55 \%$ of all farms, (regardless of sector) the farmer and/or spouse had an off-farm job. And that overall, on $81 \%$ of farms the farmer and/or spouse had some source of off-farm income be it from employment, pension or social assistance. This is in-keeping with the majority of farm households in the European agricultural sector, who are today pluriactive (Kinsella et al., 2000).

\section{Iveragh Farm Management Survey}

The Iveragh farm income statistics shown in Table 2, indicate that the overall average Family Farm Income (FFI) (excluding off-farm work) of the eighty hill sheep farms surveyed is €22,140.

\begin{tabular}{|l|r|r|}
\hline Production and income indicators $(\boldsymbol{€})$ & Mean & S.E.M \\
\hline Total gross margin & $42,340.28$ & $25,180.65$ \\
\hline . .of which subsidies for Production & $18,568.75$ & $9,575.08$ \\
\hline . of which REPS & $8,600.69$ & $3,896.45$ \\
\hline - Direct costs & 11,057 & $9,440.03$ \\
\hline = Gross margin & $31,282.99$ & $16,864.62$ \\
\hline - Overhead costs & $9,169.44$ & $12,214.64$ \\
\hline = Farm family income (FFI) & $22,139.93$ & $9,208.811$ \\
\hline . of which single farm payment (SFP) (€) & $14,467.36$ & 34.43 \\
\hline .of which single payment (SFP) (\%) & 67.83 & 13.36 \\
\hline Costs \% output & 46.22 & 40.02 \\
\hline Index of capital intensification (LU/AWU) & 60.66 & \\
\hline
\end{tabular}

Tab 2. Means and standard errors of the farms production and income indicators

(Source: Bioup Farm Management Survey, 2007-2008)

\footnotetext{
${ }^{8}$ Note this includes a once off payment of $€ 5,266$ per farm due to the carry over of arrears from the 2004 coupled payments.
} 


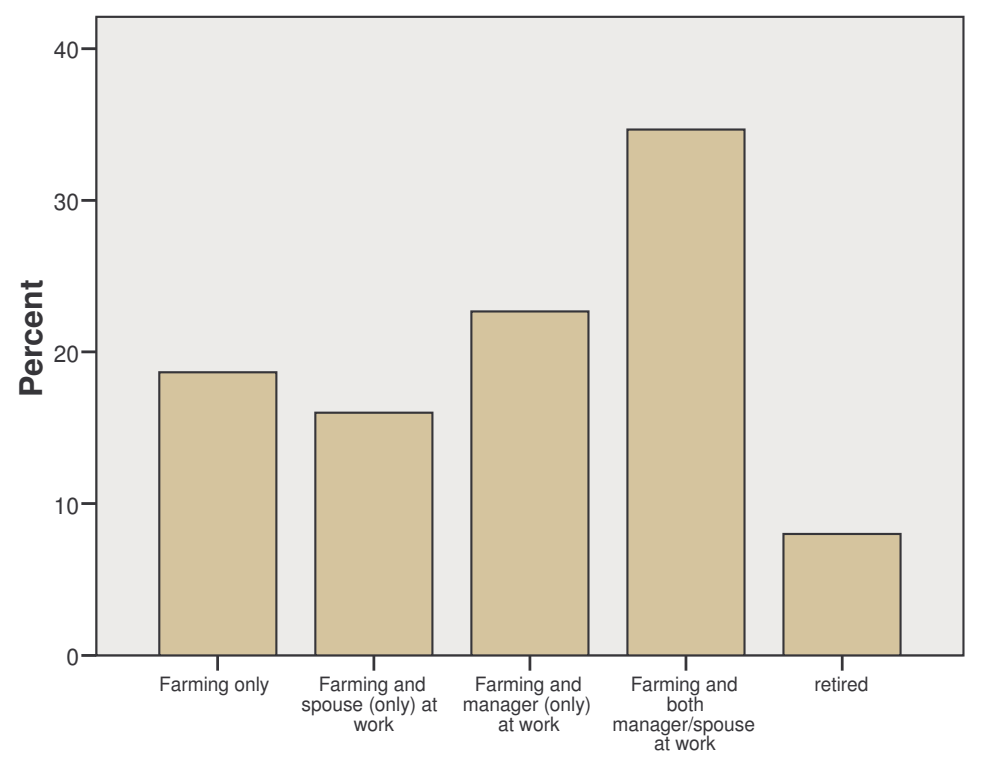

Fig 3. Farm Livelihood and Composition of Labour/Income (Source: Bioup Farm Management Survey, 2007-2008)

That income is essentially composed of the Single Farm Payment (68\%) and the agrienvironmental (REPS) payment. The Iveragh farm survey also indicates that only $19.4 \%$ of households were fully dependent on their farms as their sole source of income, (many of whom were bachelors). The average farm manager's age was 48.1 years. Figure 3, provide details on farm households other sources of income. Overall, the statistics indicate both the importance of the family farm income, as well as the necessity for off-farm work.

The general consensus on the ground is that the future of farming in the Iveragh uplands will involve combining part time farming with a full time off-farm job. Given the recent 'Celtic Tiger' economic boom that Ireland has enjoyed, finding off-farm work was not difficult, provided one was prepared to commute, sometimes a fairly long distance to local towns, such as Tralee and Killarney. The findings of the farm survey and interviews indicate that most of the Iveragh sheep farmers found work in the local booming construction sector. Table 3, indicates that construction constituted $20 \%$ of the surveyed farm operators off-farm occupation. The 2006 population census data for the Cahersiveen Rural District, which covers most of the peninsula, found that $20 \%$ of the male population was employed in the Farming, Fishing and Forestry sector and $23.5 \%$ were employed in the building and construction sector (CSO, Census of Population Small Area Population Statistics, 2006). Ireland has entered a more challenging economic period, and since 2008 there has been a distinct fall-off of employment in the construction sector. The current model of combining full-time off-farm work with part-time farming may not be sustainable in the future. There is still a strong attachment to the land, especially among the older generation of farmers, but many of them are struggling to find a successor who will continue the tradition, and divide themselves between the demands of off-farm work and parttime farming. Figure 4 , indicates that almost $50 \%$ of the surveyed farm managers did not have a definite successor.

\section{Multifunctionalism}

Multifunctionalism is a unique feature of European Agriculture, and refers to the fact that ones activities can have different outputs, such as quality food production, biodiversity conservation, countryside management and tourism (Van Huylenbroeck, 2007). Pluriactivity refers to the involvement in off-farm paid employment by either the farm operator and /or spouse. Agriculture no longer derives its legitimacy solely from its economic role in producing raw agricultural materials, but also from the provision of landscape and ecosystem services, public goods and the production of social and cultural ties (Dufour et al., 2007). The current orientation in European agriculture policy is aptly captured by what Potter \& Tilzey's (2005) refer to as a 'bimodal' model, committed, on the one hand, to corporate driven, intensive agriculture that can compete on globalised markets; while on the other hand acknowledging the role of 


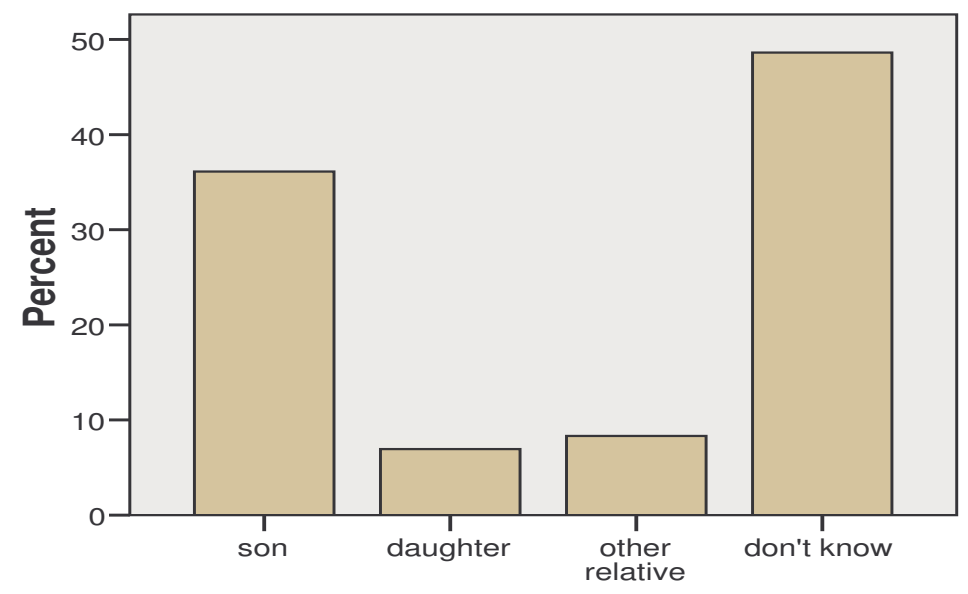

Fig 4. Potential Farm Successors Source: Bioup Farm Management Survey, 2007-2008

'traditional' agriculture in maintaining the considerable environmental and aesthetic assets of the European countryside, along with its social cohesion.

The so called European Model of Agriculture, and the EU 'Living Countryside Agenda', acknowledges the need to retain some element of income support for farmers in less favoured areas, in order to compensate for the free market's failure to value essential environmental services and public goods, valued by society as a whole. Public goods, such as rural landscapes also play a critical role in European identity and heritage, and are important for spinoff industries, such as tourism.

The multifunctional activities that farmers in disadvantaged areas, like the Iveragh, are encouraged or expected to get involved in, are things like agri-tourism, the development of niche markets for high value food products, and the provision of environmental services, for example, via agri-environmental schemes. Given the Iveragh's spectacular scenery and well developed tourist industry in the nearby towns, it would appear to be well placed to tap into the 'multifunctional agricultural model'. But, that is not what we have found on the ground. Apart for involvement in REPS, agri-environmental scheme, the majority of the upland farmers surveyed and or their spouses have opted for off-farm work, rather than diversifying their income generating farm activities. Only $18 \%$ of the surveyed farmers provided income generating tourist services (agi-tourism). A 2004 survey undertaken by the tourism steering group of the Kerry County Development Board found that of the estimated 1.8 million tourists who visit the region annually, $49 \%$ stayed in hotel, $23 \%$ in guesthouse, and only $1 \%$ opting for farm house accommodation (Kerry County Council Development Board, 2004). Our informants spoke about the seasonal nature of tourism, the capital investment necessary to reach the high tourist standards of today; along with the need to be a marketing expert as well as farmer, chef, tourist operator etc. Kerry hoteliers have benefited from a series of lucrative Government tax breaks, to the extent that there is now over capacity in the hotel sector, and prices are competitive. Rural areas are also hit by increasingly strict drink driving enforcement laws, which impacts on tourists evening entertainment options. The majority of tourists visiting the region stay in such urban centres as Killarney, Dingle, Kenmare, and take a day trip around the Ring of Kerry. For example, the picturesque village of Sneem, is a stop-off point for several coach tours on the Ring of Kerry. When the coaches arrive the tourist oriented souvenir shops are bustling for a few hours, but all is quiet by evening time, when the coaches have gone back to Killarney, and the few Bed and Breakfasts establishments around Sneem are struggling to remain open, even over the summer months. The rural farm Bed and Breakfast business is in decline. Granted, tourism provides some trickle down employment, but the catering industry is known for its low paid seasonal work, which is today increasingly filled by migrant workers. The farmers argue that it is the hoteliers in the local towns that benefit most from the natural countryside heritage that they maintain.

The local farming organisations point to the difficulty in bringing out food labels, such as organic or Kerry Lamb. There are several technical and hygiene standards to be meet, one also need marketing expertise to promote and market the product. One is also reminded of the difficulties 
in 'finishing' the lamb, because at the moment store lamb that comes off the mountain is too light. The cost of buying-in food stuff to fatten the lambs would substantially reduce any profits. Perhaps the biggest obstacle of all is the lack of an entrepreneurial spirit and institutional backup support in actually developing quality food labels. A local quality lamb label would financially reward farmers for the provision of public goods, and also re-legitimise hill sheep farming. For the moment, off-farm work is seen as an easier option and a critical livelihood strategy for marginal farm households. The lack of enthusiasm for multifunctional agriculture is not confined solely to the peripheral Iveragh. A comprehensive study undertaken in France by Dufour et al. (2007), found that multifunctionlism had greatest support among researchers and agri-administrators, rather than among farmers on the ground, whose identity is still strongly linked with farming and producing a product, rather than selling a service or an image. Similarly, a recent study in Belgium found that only $5 \%$ of total income in the farming sector comes from diversified activity of which the major part is linked to agri-tourism and direct sales (Van Huylenbroeck, et al., 2007). High value agricultural products still form too small a share of food consumption to redirect agricultural production, and there are already signs of market saturation. Strijker (2005) estimates that in 2000, high value agricultural produce, including the organic sector, accounted for below $1 \%$ of the total turnover of the European agricultural sector.

\section{Conclusion}

Extensive field work among the Kerry hill farmers, points towards the fact that it is ultimately attachment to the land, tradition and family history that binds the current generation of sheep farmers to their hills (see Figure 5). A comparable micro-survey among pluriactive farming households in County Clare, Ireland, by Kinsella et al. (2000; 487), also found 'socio-cultural motivation as the main reason for 'continuing' or taking up farming'. A survey by Lobley and Potter (2004:508) of 255 farm households in different geographical areas, and involved in different farming sectors in Britain, came to a similar conclusion: the 'respondents commitment to staying on the land remains strong and there is a sense in which this consideration will be the main driver of future behaviour'. Only $26 \%$ of our survey respondents felt that farming alone could provide an acceptable standard of living; yet $87.5 \%$ was confident that they would stay farming. This 'resilience' along with farmer's adaptive strategies and mental-models, needs to be factored into the complex social-ecological system that underpins the current and future management of European uplands.

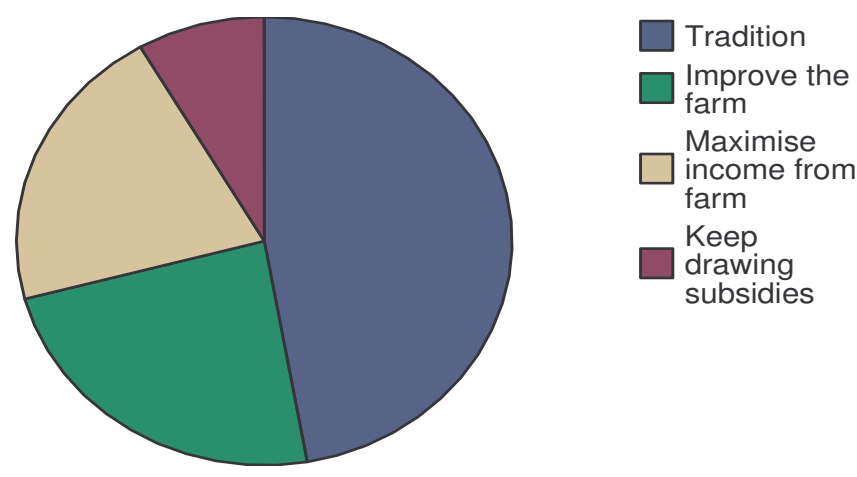

Fig 5. Farm operator's main aims in running the farm (Source: Bioup Farm Management Survey, 2007-2008)

Farming households are re-adjusting and slowly restructuring rather than exiting farming. However, in agreement with Lobley \& Potter (2004), we believe that the economic centrality of agriculture at a household level looks set to decline further. Diversification of income and multifunctional businesses are the dominant current and future farm household coping strategies. Given the poor infrastructure in South Kerry, and the lack of training and government support for farm diversification, the continued availability of off-farm work is critical. The Iveragh's elderly farmers, without successors are the most at risk of getting out of farming. The part-time farming model, which is already the norm, has ecological implications for the management of high nature value upland habitats. We already remark the trend towards moving farming down slope, and concentrating the farming system around the reclaimed 'green land', and the less intensive use of the upland rough grazing and commonages. The abandonment, or 
rather the withdrawal of effective management, from the uplands will have biodiversity and other ecological consequences.

The Single Farm Payment, along with agri-environmental (REPS) payments, is a critically important safety net for hill sheep farmers. The highly subsidised farmers in places like the Kerry hills are increasingly being defined as 'service providers', and 'countryside managers'. The policy model for hill farming is clearly moving from one of production to one of public goods provision. Rather than the current application of blanket agri-environmental subsidies (with very debatable results - cf. Emerson \& Gillmor, 1999; Feehan et al., 2002), one could argue for more targeted subsidies in the future, based on clearly defined environmental deliverables. There are signs in countries like the UK and Sweden that this is already happening. In $2005,45 \%$ of the CAP budget was spent on structural policy and rural development, as opposed to $40 \%$ for market price support. The increasing importance of the so called 'Second Pillar' of the CAP, will have implications for rural development, and may see funds moving out of the traditional rural agricultural sector. Alternatively, the increasing funding of rural development may stimulate offfarm work options; once more pointing towards a diversified, multifaceted rural, that is no longer solely synonymous with agriculture. But, agriculture remains singularly important in rural Ireland and elsewhere in Europe. To paraphrase Lafferty et al. (1999), agriculture is still considered the most important single industry in the economy of the Republic of Ireland. Twenty percent of the male population on the Iveragh's isolated Cahersiveen Rural District are involved in farming as opposed to 6.4\% nationally (CSO-Census of Population, 2006). In terms of the Living Countryside Agenda, that underpins the 1999 CAP reform, rural development and the maintenance of viable rural communities and services, such as, shops, schools, post offices and public transport, is critical. As MacLeod (1997) put it, living communities remain the most important element in the natural heritage. In European uplands we cannot disassociate the natural from the cultural. As the custodians of the landscape and its traditions from generation to generation, farmers must continue to play a pivotal role in both quality food production and countryside management They also have to be flexible and adapt to changing times. Soliva et al. (2008:69), argued that European mountain areas need to make the transition from 'less favoured' agricultural regions to 'highly-valued' environmental landscapes. Our research indicates that effective policies for the conservation of mountain biodiversity and habitats, must take account of the social and economic objectives of farming families, as well as the environmental ones, in an integrated sustainable manner.

\section{Acknowledgement}

This research is funded by Science Foundation Ireland (SFI), under the Research Frontiers Programme. We would also like to acknowledge the contribution of the rest of the 'Bioup' team, Roz Anderson, John O'Halleron, Mark Emmerson and Nick Chisholm.

References

[1] ANDERSON, R. (2008). The Vegetation of the Iveragh Uplands, Unpublished Bioup, Project Report, Cork: ERI, UCC.

[2] BALL, D., DALES, J., SHEAIL, J. \& HEAL, O. (1982). Vegetation Change in Upland Landscapes. Cambridge: Institute of Terrestrial Ecology.

[3] BALDOCK, D., BEAUFOY, G., BROUWER, F., \& GODESCHALK, F. (1996). Farming at the Margins. London, The Hague: IEEP, LEI-DLO.

[4] BERGER, J. (1992). 'A Different Answer', in, Keeping a Rendezvous. London: Granta Books.

[5] BIGNALL, E., \& MCCRACKEN, D. (1996). Low Intensive Farming Systems in the Conservation of the Countryside. Journal of Applied Ecology, 33, 416-424.

[5] Bioup-Farm Management Survey (2007-2008), conducted by N. Kramm. 
[6] BLEASDALE, A. (1995). The Vegetation and Ecology of the Connemara Uplands, with Particular Reference to Sheep Grazing. PhD Thesis, Galway: National University of Ireland.

[7] BLEASDALE, A. \& SHEEHY-SKEFFINGTON, M. (1995). 'The upland vegetation of northeast Connemara in relation to sheep grazing'. In D.W. Jefferey, M.B. Jones \& J.H. McAdam (Eds.), Irish Grasslands, their biology and management. Dublin: Royal Irish Academy.

[8] Central Statistics Office (CSO). Agricultural Census 1933 to 2000. Dublin.

[9] Central Statistics Office (CSO). Census of Population 2006 - Small Area Population Statistics. Dublin.

[10] DARLING, F.F. \& BOYD, J.M. (1969). The Highlands and Islands. London \& Glasgow: The Fontana New Naturalist,.

[11] DI FALCO, S. \& van RENSBURG, T. (2004). Rural Institutions and Natural Resource Exploitation: The case of Irish Commonage. Denver: American Agricultural Economics Association.

[12] DUFOUR, A., MAUZ, I., RÉMY, J., BERNARD, C., DOBREMEZ, L., HAVET, A., PAUTHENET, Y., PLUVINAGE, J., \& TACHAKÉRIAN, E., (2007). Multifunctionality in Agriculture and its Agents: Regional Comparisons. Sociologia Ruralis, 47(4) 316-342.

[13] DUNNE, F. (2000). Blanket Bog, Heath and Upland Grassland Exclosures: baseline Survey and Monitoring Methodology. A Report Commissioned by National Parks and Wildlife Service, Dúchas - The Heritage Service, Department of Arts, Heritage, Gaeltacht and the Islands, Dublin.

[14] EMERSON, H., \& GILLMOR, D. (1999). The Rural Environmental Protection Scheme of the Republic of Ireland. Land Use Policy, 16, 235-245.

[15] FEEHAN, J., GILLMOR, D., \& CULLETON, N. (2002). The Impact of the Rural Environment Protection Scheme (REPS) on Plant and Insect Diversity. Irish Journal of Agri-Environmental Research, 2.

[16] FLURY, C., GOTSCH, N., \& RIEDER, P. (2005). Site-specific and regionally optimal direct payments for mountain agriculture. Land Use Policy, 22(3), 187-280.

[17] HARDING, G. (1968). The Tragedy of the Commons, Science 162, 1243.

[18] Irish Farmers Association (2008). Mr. Padraig Walsh - President, Radio Interview RTE1 Farm Week, May $3^{\text {rd }}, 2008$.

[19] Kerry County Development Board (2004). County Kerry Tourism Research, Tralee: Kerry County Council.

[20] KINSELLA, J., WILSON, S., de JONG, F., \& RENTING, H. (2000). Pluriactivity as a Livelihood Strategy in Irish Farm Households and its Role in Rural Development. Sociologia Ruralis, 40(4) 481-496.

[21] KRAMM, N., O'ROURKE, E., \& CHISHOLM, N. (2008). Modelling the impact of land use decisions on agriculture, biodiversity and socio-economic development of the Irish upland commons. In Proceedings of the International Association for the Study of Commons, (IASC), July, 14-18, Cheltenham, UK.

[22] LAFERTY, S., COMMINS, P. \& WALSH, J. (1999). Irish Agriculture in Transition: A Census Atlas of the Agriculture of the Republic of Ireland. Teagasc in association with the Department of Geography, NUI, Maynooth, Co. Kildare.

[23] LOBLEY, M. \& POTTER, C. (2004). Agricultural Change and Restructuring: recent evidence from a survey of agricultural households in England. Journal of Rural Studies, 20, 499-510.

[24] MACDONALD, A. \& ARMStRONG, H. (1989). Methods of Monitoring Heather Cover. Peterborough: Nature Conservancy Council,.

[25] MacDONALD, D., CRABTREE, J., WIESINGER, G., DAX, T., STAMOU, N., FLEURY, P., GUTIERREZ LAZPITA, J., \& GIBON, A. (2000). Agricultural Abandonment in Mountain 
Areas of Europe: Environmental consequences and policy response. Journal of Environmental Management, 59, 47-69.

[26] MHICDAEID, C. (1976). A phytosociological and ecological study of the vegetation of peatlands and heaths in the Killarney Valley. PhD. Thesis. Dublin:Trinity College.

[27] MACLEOD, C. Labour plans for radical reform. (1997 February 22). The Herald.

[28] O'ROURKE, E. (2008). Iveragh's Uplands: Farming, Nature and Society. In: J. Crowley \& J. Sheehan (Eds.), The Iveragh Peninsula: Landscape, History, Culture. Cork: Cork University Press.

[29] PEARSALL, W. H. (1968): Mountains and Moorlands. London \& Glasgow: The Fontana New Naturalist.

[30] POTTER, C. \& TILZEY, M. (2005). Agricultural policy discourse in the European postFordist transition: Neoliberalism, neomercantilism and multifunctionality. Progress in Human Geography 29(5), 581-600.

[31] RATCLIFFE, D.A. (1959). The Vegetation of the Carneddau, North Wales, 1 Grasslands, Heaths and Bogs. Journal of Ecology, 47, 371-413.

[32] SOLIVA, R., RONNINGEN, K., BELLA, I., BEZAK, P., COOPER, T., FLO, B., MARTY, P., \& POTTER, C. (2008). Envisioning Upland Futures: Stakeholder responses to scenarios for Europe's mountain landscapes. Journal of Rural Studies, 24(1), 56-71.

[33] STRIJKER, D. (2005). Marginal Lands in Europe - Cause of Decline. Basic and Applied Ecology, 6(2), 99-106.

[34] TEAGASC $(2003,2005)$. National Farm Survey. Rural Economy Research Centre, Athenry, County Galway. (www.agriculture.gov.ie)

[35] THOMPSON, D., MACDONALD, A., MARSDEN, J., \& GALBRAITH, C. (1995). Upland Heather Moorland in Great Britain: A review of the international importance, vegetation change and some objectives for nature conservation. Biological Conservation, 71, 163-178.

[36] USHER, M.B. \& THOMPSON, D.B., Eds. (1988). Ecological Change in the Uplands. Oxford: Blackwell Scientific Publications.

[37] VAN HUYLENBROECK, G. et al. (2007). Multifunctionality of Agriculture: A Review of Definitions, Evidence and Instruments. Living Reviews in Landscape Research, 1, 5-43. http://www.livingreviews.org//rlr-2007-3.

[38] WATHERN, P. (1992). Less Favoured and Environmentally Sensitive Areas: A European Dimension to the Rural Environment. In W. Howarth \& C. Rodgers (Eds.), Agriculture, Conservation and Land Use. Cardiff: University of Wales Press.

[39] WINTER, M., GASKELL, P., \& SHORT, C. (1998). Upland Landscapes in Britain and the 1992 CAP Reforms. Landscape Research, 23(3), 273-288. 